\title{
A Case study of Empowerment of Muslim women through education in India
}

\author{
Iftekhar Unissa
}

\author{
Department of English, Anwarul Uloom College, Mallepally, Hyderabad.
}

\begin{abstract}
According to natural policy for the empowerment of Muslim women in India 2001.It describes role of educator in Indian Muslim women, special measures to be taken to eliminate discrimination secondary and higher education should be most of the women are not aware of their rafters given by Islam the religion to which they belong. To inculcated awareness of their status. Security equality and the Constitution of the country to which they belong him India. Curricula to be developed at all levels of education system for the backward and schedule castes among the Indian Muslims. Socially and economically the Indian Muslim waver and backward. This is a major problem which should be sorted out with the government natural policy 2001 introduced for their up left menu.
\end{abstract}

Keywords - Women empowerment, Sachar Committee, aware, discriminate, curricula, constitution.

\section{INTRODUCTION}

In the contemporary age of globalization, women empowerment becomes an important issue.

Empowerment means to increase the spiritual, political, social or economic strength of individual and communities by developing confidence in their own capacities. Empowerment refers the right to determine choices, right to have access to opportunities and resources for taking proper decision. The status of Muslim women in India remains comparatively inferior to that of men though women are working in Educational institutions, Multinational companies, Medical field, Banks, NCC, Army and other financial institutions. They are still neglected tortured and dominated by male society.

According to the latest March 2017, PEW a US-based think tank they estimated change from 2010 to 2015 is $73 \%$, for the number of Indian Muslim women is projected to rise more than 300 million by 2015, Making in India the country with the largest Muslim population.

According to the Sachar Committee report as a result of such biased propaganda the civil society and the state locate Muslim women's deprivation not in terms of the 'objective' reality of societal discrimination and faulty development policies, but in the religious community space.

The problems of the Muslim women are much different and more complex than their counterparts belonging to other religions. Muslims since independence have lived in a fear, they have been ignored by successive Governments and sometimes they have been targeted the community and women being the most vulnerable have been exposed to all sort of violence. As of the India Muslim women are illiterate. Without proper education and knowledge, they are not even able to take up their cases and obtain justice.

The problem is that only legal provisioning is not enough to ensure women's right in India. Our society is still not relaxed enough to accept women equal to their men counterparts. In this perspective, education is thought to be the perfect ladder for women.

Objectives

1) To study the present educational status of Muslim women in India

2) To identify the problems regarding the education of Muslim women.

3) The problem is that in India no political party shows any understanding of how to shape a modernist path for Muslim women.

\section{METHODOLOGY}

This is an empirical study. The researchers have used secondary data.

\section{Defining women empowerment}

Empowerment is a broad term. Better to say, it is a kind of umbrella term. In the broadest sense, empowerment is the freedom of choice and action. It also can be defined as a process of enabling someone to think, act and control in a unique way. UNESCO defines empowerment as “... the expansion of assets and capabilities of poor people to participate in, negotiate with, influence, control, and hold accountable institutions that affect their lives." An empowered person can have the necessary control over his or her destiny and life. And this includes control over physical, intellectual and financial resources as well as 
ideologies. According to Hashemi Schuler and Riley (1996), the term empowerment also can be viewed as means of creating a social environment in which one can make decisions and make choices either individually or collectively for social transformation. It strengthens the innate ability by way of acquiring knowledge, power, and experience. Another definition may be added, according to the Report of Government of India, "Empowerment means moving from a position of enforced powerlessness to one of power".

Empowerment of women means the process of upliftment of economic, social and political status of women who are the generally belong to the underprivileged ones in the society. Women empowerment speaks to create a sociopolitical environment where women can live without the fear of oppression, exploitation, apprehension, discrimination and the general feeling of persecution which goes with being a woman in a traditionally male-dominated structure. The concept of women empowerment was officially launched by UN in Cairo Conference in 1994. 1995 UNDP report was devoted to women empowerment. In World Summit 2005, all nations agreed that progress for women is progress for all.

Therefore, in gross, women empowerment denotes equal participation of women with men in social, political, financial and other issues. In India, traditionally women are the neglected ones. They are deprived of their rights. Maledominated society always suppressed the voice of women in India. It is a long cherished dream of the women to claim a world which will allow them to have their own life.

\section{The approach of Indian Constitution to Women Empowerment}

We may have heard names of educated women like Gargi, Opala or Maitryee in our ancient India, but India in a later stage got famous for oppressing rights of women. In our society, women are used for house-work and breeding child. They are not also allowed to speak loudly.

After independence, the constitution of India provided basic support to reclaim women's right. Article 15 states that Government shall not discriminate against any citizen on the ground of sex. Article 15 (3) denotes a special provision enabling the state to make affirmative discriminations in favor of women. The constitution regards a fundamental duty of every citizen through Articles 15 (A), (E) to renounce the practices derogatory to the dignity of women. The Government of India declared 2001 as the Year of Women's Empowerment (Swashakti).The National Policy for The Empowerment Of Women bill was passed in 2001.
On 9 March 2010, one day after International Women's day, Rajya Sabha passed the Women's Reservation Bill requiring that $33 \%$ of seats in India's Parliament and state legislative bodies be reserved for women. The National Mission for Empowerment of Women (NMEW) was launched by the Government of India (GoI) on International Women's Day in 2010 with the aim to strengthen overall processes that promote all-round Development of Women. The mission statement is "To strengthen the processes which promote holistic development and empowerment of women, gender equality and gender justice through the inter-sectoral convergence of programmes that impact women, forge synergy among various stakeholders and create an enabling environment conducive to social change.

On 9 March 2005, under the Chairmanship of Justice Rajinder Sachar, a Committee was constituted for preparation of a Report on the Social, Economic and Educational Status of the Muslim Community of India. The Report was submitted in November 2006.

\section{Role of Education in Women Empowerment}

Education is always regarded as the highest instrument of women empowerment. Education can build the necessary confidence among the women to claim their world. Proper education can help to engage them in socio-political changes of the world as well as in the financial developments. Moreover, the education will ensure their full and individual participation along with men. Education can also open the gate of employment to the women. From the self-help groups to private and government employment, women can be financially independent. And this independence can enable their individual decisionmaking position in the society. In gross, education can help women to establish their individuality and equal rights.

\section{Muslim women of India}

According to Census 2011, 17.22 crore Muslims constitute $14.23 \%$ of total population in India. Earlier, Sachar committee has reported that around 31\% Muslims live below poverty line. Poverty, unemployment, and illiteracythese are the curses on the Muslim community in this country. Among the Muslim population, approx $48 \%$ of them are women. These Muslim women are one of the endangered sections regarding the issue of empowerment in India. 2011 Census has shown that $42.7 \%$ Muslims are illiterates in India. More than 50\% Muslim women are illiterate in India. This illiteracy may affect the process of empowerment. 
In case of higher education, according to National Sample Survey 2009-10, 11 out of 100 Muslims take the higher education in India. This data is enough to show the poor status of Muslims in higher education scenario. According to the report of Sachar Committee, only $4.4 \%$ Muslim entered in the graduate studies in 2004-05.

According to the Census 2001, the work participation rate of Indian Muslim women is $14.1 \%$. According to NSS $55^{\text {th }}$ round Survey on Employment, 2000, just $6.03 \%$ graduate Muslim women have been found in urban areas and in the rural areas, the percentage was $1.22 \%$.

\section{Reasons for backward condition}

\section{Socio-cultural challenges}

1) The dominance of Patriarchy: Muslim community is still dominated by the shackles of patriarchy. The women life and dreams are controlled by the male members. The educational prospect of a girl child in a Muslim family fully depends on the will of the male members of the family.

2) Religious rigidity: The rigid nature of Islam frames a tough condition for women's freedom. The women are not allowed any kind of independence without men recognition.

3) Gender inequality: The examples of gender inequality are more prevalent in the Muslim community where a girl child is bought up only to cater the male test.

4) Social Suppression: The Muslim parents often get pressurized from the society to stop their girl child's education. They are compelled to think that over educational qualification may hamper their girl child's marriage prospects.

5) Child Marriage: In India, it is a common practice to for the Muslim girl children to get married in their adolescence. According to government reports, $47 \%$ girls get married in their adolescence in this country.

6) Child Labour: Poor families send their girl children to work as a maidservant. These children are barred from formal education.

7) Human Trafficking: National Crime Record Bureau (NCRB) reports that a number of human trafficking cases have increased $38.3 \%$ in last five years. Poverty and unemployment open the road of trafficking of girl children in these areas. Sometimes, guardians sell their girl willingly.

8) Social discrimination: In our society, a girl is born only to serve the need of the male-dominated world. A girl child is never encouraged to make own independent identity. The Muslim community is not different than others.

Economical challenges

1) Poverty: According to the Sachar Committee report, there is $31 \%$ Muslim population under the poverty line. Poverty does not encourage the guardians to send their girl children to the school.

2) Unemployment: Our formal education system does not ensure job opportunities. This is a big reason for Muslim guardian's lack of interest in their girl child's educational prospect.

\section{Infrastructural challenges}

1) The expensiveness of education: RTE speaks for free education. But, in reality, the associated expenditure of present education system is too high. Families from below poverty line, fail to afford the cost of education which results in the increasing dropout and failure of RTE.

2) Lack of infrastructure: India needs more schools and teachers to fulfill the basic requirements of RTE. The infrastructure of schools also needs to be revised to meet the need of the time.

3) Lack of scope for vocational education: due to economic necessity, most of the poor Muslim families look for early employment which can be assured through proper vocational education. But, due to lack of effort from the schools and government, vocational education is highly neglected in this district.

\section{CONCLUSION}

The entire system of viewing backwardness of Muslim women in India require a radical shift in perception and more men should support this movement

Islam believes in the creation of Adam and Eve by God Almighty. It believes that issue was also rated by the divine power. The woman, therefore, should be cherished and respected by man. He must realize that the man and the society that discards woman, in reality, disregard the unselives. The male and the female are part of the same unit and unless there are unity and understanding herein the two, the units will not he harmonious and this will adversely impact the family and the social fabric. When a man respects women, he actually respects himself. When a nation acknowledges the identity of the woman, it acknowledges its own strength.

The care of the problem is that women should not he views it calls for a change in mindset at the grassroots level. The 
time is ripe for our society to open into eyes and tackle this issue on a war footing so that in a few years time, this challenge would be a thing of the past. Let men and women walk ahead side by side and tackle issues of the family, of the community and of the country. Let them share equal responsibility and may they enjoy equal rights as respected citizens of the country. May God help us in this just endeavor!

Statistics reveal that more than $90 \%$ of the world, the property is owned by men. We must hear in mind that many social conventions in India were headed by men for eradication. For example, the practice of sati was opposes by Raja Ram Mohan Roy.

\section{REFERENCES}

[1] Shah, Mihir, Chawla, Arunish, Bakshi, Sanchita, Regional Disparities in India-A Moving Frontier, Economic \& Political Weekly, Vol 1, January 2015

[2] Census of India, 2011

[3] National Policy for the Empowerment of Women, 2001

[4] Parker, Priya, Summary of Sachar Committee Report,(2006. December,7)

[5] Islam and Muslim Societies: A Social Science Journal Vol. 5, No. 1 - 2012, www.muslimsocieties.org

[6] Report of All India Survey on Higher Education, 2014-15 